\title{
Chromium-induced alkaloid production in Catharanthus roseus (L.) G.Don in vitro cultured shoots and related gene expression patterns particularly for the novel gene $G S$
}

\author{
Elham KHATAEE ${ }^{1}$, Farah KARIMI $*^{2}$, Khadijeh RAZAVI $^{3}$
}

Received August 01, 2018; accepted January 27, 2019.

Delo je prispelo 01. avgusta 2018, sprejeto 27. januarja 2019.

\begin{abstract}
This study aimed to determine the effects of methyl jasmonate (Mj) combined with chromium $(\mathrm{Cr})$ as elicitor on production of medicinal alkaloids, its antioxidant potential, and its effects on the expression of signaling and biosynthetic enzymes. Combined treatment had positive effects on secondary metabolism and changed genes expression levels of mitogenactivated protein kinase 3 (MAPK3), a transcription factor (TF) known as octadecanoid-responsive Catharanthus AP2domain 3 (ORCA3) upstream of plant alkaloids biosynthetic pathway. Maximum expression levels of peroxidase1 ( $P R X 1)$, geissoschizine synthase (GS) (24 h-treatment), MAPK3 and ORCA3 (8 h-treatment), were 6.25-, 4.87-, 7.67-, and 5.38fold higher than control, respectively, in response to $100 \mu \mathrm{M}$ $\mathrm{Mj}+50 \mu \mathrm{M} \mathrm{Cr}$. This value was 5.92 -fold for strictosidine synthase $(S T R)$ in response to $100 \mu \mathrm{M} \mathrm{Mj}+100 \mu \mathrm{M} \mathrm{Cr}$ after $24 \mathrm{~h}$. The maximum total yield of vincristine was 1.52 -fold more than control in response to $100 \mu \mathrm{M} \mathrm{Mj}$ after one week. This increase was 2.16, 4.01, 2.39 and 1.97-fold for ajmalicine, vinblastine, vindoline and catharanthine respectively, in response to $100 \mu \mathrm{M} \mathrm{Mj}+50 \mu \mathrm{M} \mathrm{Cr}$. $\mathrm{Mj}+\mathrm{Cr}$ can elevate alkaloid production by induction of MAPK3 and ORCA3 signaling pathway, which induces expression of downstream terpenoid indole alkaloids (TIAs) biosynthetic enzymes.
\end{abstract}

Key words: antioxidative responses; chromium; $G S$; $M A P K 3$; ORCA3; real time PCR

\section{IZVLEČEK}

S KROMOM VZPODBUJENA PRODUKCIJA ALKALOIDOV PRI VRSTI Catharanthus roseus (L.) G.Don V IN VITRO GOJENIH POGANJKIH IN Z NJO POVEZANI VZORCI IZRAŽANJA GENOV, ŠE POSEBEJ NOVEGA GENA $G S$

Namen raziskave je bil določiti učinke metil jasmonata $(\mathrm{Mj}) \mathrm{v}$ povezavi s kromom (Cr) kot elicitorjev $\mathrm{v}$ produkciji medicinskih alakaloidov, njun antioksidacijski potencial in njune učinke na ekspresijo signalizacije in biosinteze encimov. Kombinirano obravnavanje je imelo pozitivne učinke na sekundarni metabolizem in spremenilo ravni izražanja genov mitogen-aktivirane protein kinase 3 (MAPK3), transkripcijskega faktorja (TF) poznanega kot oktadekanoidodzivne Catharanthus AP2-domene 3 (ORCA3), ki vzpodbuja biosintezo rastlinskih alkaloidov. Največje ravni izražanja peroksidaze1 $(P R X 1)$, geisošizin sintaze $(G S) \quad(24 \mathrm{~h}-$ obravnavanja), MAPK3 in ORCA3 (8 h-obravnavanja) so bile 6,25-, 4,87-, 7,67-, in 5,38-krat večje kot pri kontroli kot odziv na hkratno obravnavanje s $100 \mu \mathrm{M} \mathrm{Mj}+50 \mu \mathrm{M} \mathrm{Cr}$. Ta vrednost je bila za striktozidin sintazo (STR) 5,92-kratna kot odziv na $100 \mu \mathrm{M} \mathrm{Mj}+100 \mu \mathrm{M}$ Cr po 24 h. Največji celokupni pridelek vinkristina je bil za 1,52-krat večji kot pri kontroli kot odziv na $100 \mu \mathrm{M}$ Mj po enem tednu. Enako povečanje je bilo $2,16,4,01,2,39$ in 1,97-kratno za ajmalicin, vinblastin, vindolin in katarantin, kot odziv na $100 \mu \mathrm{M} \mathrm{Mj}+50 \mu \mathrm{M} \mathrm{Cr}$. $\mathrm{Mj}+\mathrm{Cr}$ lahko povečata produkcijo alkaloidov $\mathrm{z}$ indukcijo $M A P K 3$ in ORCA3 signalne poti, ki inducira izražanje encimov za biosintezo terpenoid indolnih alkaloidov (TIAs).

Ključne besede: antioksidacijski odziv; krom; GS; $M A P K 3$; ORCA3; realni čas PCR

\footnotetext{
1 Dep. of Biology, Faculty of Basic Sciences, Shahed University, 3319118651, Tehran, Iran

2 Medicinal Plant Research Center, Shahed University, 3319118651, Tehran, Iran; *corresponding author: to fkarimi@ shahed.ac.ir.

3 National Institute of Genetic Engineering and Biotechnology, 1497716316 Tehran, Iran
} 


\section{INTRODUCTION}

Catharanthus roseus L. (Apocynaceae) is a significant pharmaceutical plant that contains more than 130 alkaloids named terpenoid indole alkaloids (TIAs), 25 of which are found in nature in dimeric form and have antidiabetic, bactericide, antihypertensive, and anticancerous activities. Vincristine and vinblastine are two dimeric alkaloids that are potent antineoplastic factors and indispensable elements in most cancer chemotherapies. Additionally, two precursors of them, catharanthine and vindoline, are also of great importance. Furthermore, C. roseus is the source of ajmalicine which has been identified as an antihypertensive agent (Ncube \& Van Staden, 2015).

The pharmacological significance of TIAs and their low amounts in the plant which is the unique source of them (around $0.0005 \%$ of dry mass) have motivated broad research on the TIA pathway for manipulating plant metabolism to enhance alkaloid amounts. One important technique for raising secondary metabolite contents is the utilization of heavy metals in plant cell, tissue, and organ cultures not only to enhance the generation of secondary metabolites, but also to promote the de novo biosynthesis of them (Wójciak-Kosior et al., 2016). Chromium $(\mathrm{Cr})$ is a special example of a heavy metal that, in hexavalent $\left(\mathrm{Cr}^{+6}\right)$ form, is soluble and highly mobile (Eleftheriou et al., 2015). Methyl jasmonate (Mj) is a key element of plant's immune system that regulates the protective reactions against stresses, also participates in signal transduction chain and results in high production of TIAs (Van Moerkercke et al., 2015). The effects of $\mathrm{Cr}$ combined with $\mathrm{Mj}$ on the expression levels of key elements of the biosynthetic pathway, such as strictosidine synthase (STR), deacetylvindoline-4-Oacetyltransferase (DAT), geissoschizine synthase (GS) and a peroxidase1 (PRX1), has not yet been determined.
STR, DAT, and PRX1 are three main bottleneck steps. STR condenses tryptamine and secologanine to form strictosidine, the first monoterpene indole alkaloid. DAT acetylates deacetylvindoline to form vindoline, and then PRX1 dimerizes the vindoline and catharanthine to make dimeric TIAs. GS is a novel gene that forms 19E-geissoschizine from 4, 21dehydrogeissoschizine, one of the intermediate steps in stemmadenine biosynthesis. GS was identified by Qu et al. (2018), and to date, the expression of this gene in response to any treatment has not been studied.

The critical enzymes of the pathway and important transcription factors (TFs) affecting their activity and regulatory pathways have always been considered in elicitation studies. A manifest example of this is the octadecanoid-responsive Catharanthus AP2-domain 3 (ORCA3), a jasmonate-inducible TF that regulates many important jasmonate and elicitor responsive genes in the TIA pathway by attaching to an area in their promoter (Raina et al., 2012). In addition to TFs, mitogenactivated protein kinase (MAPK) cascades, upstream of these factors, are important in the regulation of the pathway.

Little information is available on how the plant responds to this kind of stress $(\mathrm{Mj}+\mathrm{Cr})$ at the gene expression level. Thus, the purpose of this assay was to determine the joint effects of $\mathrm{Cr}$ and $\mathrm{Mj}$ synchronically as a kind of elicitor on the production of the medicinal alkaloids vincristine, vinblastine, catharanthine, vindoline and ajmalicine; its antioxidant potential; its effects on the expression of CrMAPK3, the TF ORCA3, the biosynthetic enzymes $C r P R X 1, S T R, D A T, G S$; and finally, the relationship between alterations in gene expression and the production of TIA alkaloids.

\section{MATERIAL AND METHODS}

\subsection{Plant growth conditions and elicitor preparation}

Seeds of C. roseus var. pacifica 'XP Cherry Red Halo' procured by the Pan American Seed Company (U.S.A.) were germinated in MS medium in a growth chamber with a temperature of $25 \pm 2{ }^{\circ} \mathrm{C}$ and a 16 -h photoperiod with $400 \mu \mathrm{m} \mathrm{m}^{-2} \mathrm{~s}^{-1}$ photon flux density. After 5 weeks, shoot explants were moved to MS medium augmented with $100 \mu \mathrm{M} \mathrm{Mj}$ (Sigma-Aldrich) separately and in combination with 50 and $100 \mu \mathrm{M}$ concentrations of $\mathrm{Cr}^{+6}$ as $\mathrm{K}_{2} \mathrm{Cr}_{2} \mathrm{O}_{7}$ (Merck). For the control group, explants were cultured in basal MS medium. Treated and control samples were then harvested after 0.5, 4, 8, 24 hours (h) and one week elicitation, chilled in liquid $\mathrm{N}_{2}$, and then kept at $-80{ }^{\circ} \mathrm{C}$ until analysis.

\subsection{Lipid peroxidation}

The malondialdehyde (MDA) content represents lipid peroxidation in plant tissue, and it was measured by thiobarbituric acid reaction using the method of Heath and Packer (1968).

\subsection{Total phenolic and flavonoid contents}

To evaluate total phenolic content, the Folin-Cio-calteu method was used (Dewanto et al., 2015). $0.5 \mathrm{ml}$ of deionised water and $125 \mu \mathrm{l}$ of the Folin-Cio-calteu reagent were added to $125 \mu$ l of the diluted sample extract. After standing for $6 \mathrm{~min}$ and then adding $1.25 \mathrm{ml}$ of a $7 \%$ aqueous $\mathrm{Na}_{2} \mathrm{CO}_{3}$ solution, the ultimate 
volume was arranged to $3 \mathrm{ml}$ with water. Consideration was performed after $90 \mathrm{~min}$ in $760 \mathrm{~nm}$. The results were expressed as $\mathrm{mg}$ gallic acid equivalents per $\mathrm{g}$ fresh mass(mg GAE $\left.\mathrm{g}^{-1} \mathrm{FM}\right)$. Flavonoid content was determined using a colorimetric method that was explained by Dewanto et al. (2015). $0.05 \mathrm{ml}$ of a $33 \%$ aqueous acetic acid solution and $0.1 \mathrm{ml}$ of a newly made $10 \% \mathrm{AlCl}_{3}$ solution were added to $0.5 \mathrm{ml}$ of the suitably diluted sample. By using ethanol, the ultimate volume was reached to $2.5 \mathrm{ml}$ and after $30 \mathrm{~min}$, absorption of samples was read at $414 \mathrm{~nm}$. The outcomes were displayed as mg quercetin equivalents per $\mathrm{g}$ fresh mass(mg $\left.\mathrm{QE} \mathrm{g}^{-1} \mathrm{FM}\right)$.

\subsection{Alkaloid extraction and analysis}

Alkaloids were extracted according to Miranda-Ham et al. (2007). To determine the content of vincristine, vinblastine, catharanthine, vindoline and ajmalicine, a quantitative HPLC by a Knauer GmbH HPLC system was used. A5 $\mu \mathrm{m} \mathrm{C} 18$ vertex column $(125 \mathrm{~mm} \times 4 \mathrm{~mm}$ ID) was applied for the separation of samples. A volume of $20 \mu \mathrm{l}$ was injected, and the column temperature was $25^{\circ} \mathrm{C}$. The mobile phase was made up of a blend of $5 \mathrm{mM} \mathrm{Na}_{2} \mathrm{HPO}_{4}$ (pH adjusted to 6 with $\mathrm{H}_{3} \mathrm{PO}_{4}$ ) (solvent A) and acetonitrile (solvent B). Flow-rate was $1.0 \mathrm{ml}$ $\min ^{-1}$. The UV detector of the HPLC system was adjusted at $258 \mathrm{~nm}$. Alkaloids were computed as $\mu \mathrm{g} \mathrm{g}^{-1}$ DW. Total alkaloid content was counted at $280 \mathrm{~nm}$ using a UV-VIS spectrophotometer (Vario 2600).

\subsection{Protein content and assays of antioxidant enzyme activity}

Bradford's method was used to consider the protein content. Catalase (CAT; EC 1. 11.1.6), peroxidase (POD; EC 1. 11.1.7), and superoxide dismutase (SOD; EC 1. 15.1.1) activities were determined by standard methods as previously described in Sanchez-Rojo et al. (2015).

\subsection{RNA extraction, cDNA synthesis, and gene expression}

Total RNA was extracted from in vitro-cultured $C$. roseus plantlets $(0.1 \mathrm{~g})$ using RNX plus (Cinnaclon). The qualities and concentrations of the extracted RNA were checked with agarose gel electrophoresis and spectrophotometer, respectively. After DNaseI treatment, the first strand of cDNA was synthesized from $6 \mu \mathrm{g}$ of total RNA using an oligo-d (T) primer. Reverse transcription was performed using the following program: $37^{\circ} \mathrm{C}$ for $15 \mathrm{~min}, 85^{\circ} \mathrm{C}$ for $5 \mathrm{~s}$ and $4{ }^{\circ} \mathrm{C}$ as a final hold. The sequence of oligonucleotide primers used for study was as follow: $\mathrm{F}$ : $M A P K 3$ (5'-CGAAAACATAATTGCCATAA-3'), R: MAPK3 (5'-TGACAATGCTCCTCAGATAGA-3'), F: ORCA3 (5'-CAGGAGGATTCTGTTGTGG-3'), R: ORCA3 (5'-CTGGATCCTTTCTTTTTCG-3'), F: $\quad$ PRX1 (5'-TCACTTCTGACCAAGATTTGTA-3'), R: $P R X 1$ $\left(5^{\prime}\right.$-CTTGATTCCCCGTTAACAC- $\left.3^{\prime}\right), \quad$ F: $\quad R B C L$ (5'-GCTGCTGAATCTTCTACTGG-3'), R: $\quad R B C L$ (5'-GTCTAAGGGGTAAGCTACATAAG-3'), F: STR (5'-GGTTCTACACTTCCGTCCA-3'), R: $\quad$ STR (5'-CAATGGTCTTTTCTCTGGATC-3'), F: DAT (5'-CCAAGCTATTAATTTACGTCC-3'), R: DAT (5'-CTTTCCTTAGCTCATTAATCACT-3'), F: $G S$ (5'-GTGAACGGGATGTGAAGAT-3'), R: $G S$ (5'-TCTCTACTTTGCTGCCAACT-3'). Real-time quantitative RT-PCR amplification was accomplished using PrimeScript TM RT Reagent Kit (Takara) according to the manufacturer's instructions. PCR conditions consisted of a $95^{\circ} \mathrm{C}$ for $2.5 \mathrm{~min}, 40$ cycles of $95{ }^{\circ} \mathrm{C}$ for $15 \mathrm{~s}, 78^{\circ} \mathrm{C}$ for $15 \mathrm{~s}$ and $72{ }^{\circ} \mathrm{C}$ for $20 \mathrm{~s}$. The abundance of targeted genes transcripts was normalized to $r b c l$ mRNA and was determined by the standard $2^{-\Delta \Delta C T}$ method of Livak and Schmittgen (2001).

\section{RESULTS AND DISCUSSION}

\subsection{Alkaloid contents}

As it was considered before, the low levels of dimeric anticancer drugs, their costliness, and their difficult chemical biosynthesis have attracted the attention of many researchers and prompted them to find ways to optimize the production of these TIAs. Using $\mathrm{Cr}+\mathrm{Mj}$ as an inducer and studying the responses of the plant to this abiotic stress and examining individual gene expression in the biosynthetic pathway and the relationship between genes and the construction of TIAs could enhance the comprehension of the whole interplay. Previous researches explained that heavy metals, when applied in low concentrations, in most cases causes positive effects and increased metabolite production (Wójciak-Kosior et al., 2016). Also Mj has been proved to be able to elicit the production of several compounds (alkaloids, terpenoids and phenolic phytoalexines) in many plant species (Van der Fits \& Memelink, 2000). The present investigation found that after 0.5 and $8 \mathrm{~h}$ treatment there wasn't any significant difference between groups. After $4 \mathrm{~h}$-treatment, only $100 \mu \mathrm{M} \mathrm{Mj}+100 \mu \mathrm{M} \mathrm{Cr}$ and $100 \mu \mathrm{M} \mathrm{Mj}+50 \mu \mathrm{M} \mathrm{Cr}$ caused a significant increase in ajmalicine and vinblastine respectively. After 24 h-treatment, $\mathrm{Mj}$ separately and in combination with two concentrations of $\mathrm{Cr}$ significantly elevated vincristine content compared to control but the content of vinblastine, ajmalicine and catharanthine significantly increased only in joint treatment. About vindoline, only $100 \mu \mathrm{M}$ 
$\mathrm{Mj}+50 \mu \mathrm{M}$ Cr significantly increased it compared to control. The maximum total yield of vincristine was 1.52 -fold more than control in response to $100 \mu \mathrm{M} \mathrm{Mj}$. This increase was $2.16,4.01,2.39$ and 1.97 -fold for ajmalicine, vinblastine, vindoline and catharanthine respectively, in response to $100 \mu \mathrm{M} \mathrm{Mj}+50 \mu \mathrm{M} \mathrm{Cr}$ (Figures 1a, 1b, 1c, 2a, 2b). $\mathrm{Mj}$ alone and combined with 50 and $100 \mu \mathrm{M} \mathrm{Cr}$ significantly increased total alkaloids after 4, 8, 24 and one week of treatment (Figure 2c). So, this result confirmed earlier reporters on TIA biosynthesis under Copper treatment (Pan et al., 2015) or Mj application (Peebles et al., 2009). Also it can be deduced that the highest values for all alkaloids were observed after application of two treatments simultaneously that shows the additive effects of combined treatments on increasing alkaloid. Reduction in $100 \mu \mathrm{M} \mathrm{Cr}$ treatment is probably due to the effects of high concentration of metal and gradual degredation of the plant. This improvement in indole alkaloid production may also be explained by the activation of the transcription of their biosynthetic genes.

\subsection{Gene expression analysis}

In the current study, qRT-PCR was used to study PRXI, $D A T, S T R, G S, O R C A 3$, and MAPK3 transcripts in response to $\mathrm{Mj}+\mathrm{Cr}$. As seen in Figure 3, when exposed to $100 \mu \mathrm{M}$ of $\mathrm{Mj}$ combined with 50 and $100 \mu \mathrm{M}$ of $\mathrm{Cr}$, the expression of PRXI,DAT, STR, and GS increased significantly compared to control. The maximum expression level of $P R X 1$ and $G S$ were obtained after $24 \mathrm{~h}$ treatment and was 6.25 and 4.87 -fold respectively in response to $100 \mu \mathrm{M}$ of $\mathrm{Mj}+50 \mu \mathrm{M}$ Cr. $D A T$ expression levels didn't show any significant difference in response to $100 \mu \mathrm{M}$ of $\mathrm{Mj}+50$ and $100 \mu \mathrm{M} \mathrm{Cr}$ after $24 \mathrm{~h}$. The maximum expression level of $S T R$ was obtained after $24 \mathrm{~h}$ of treatment and was 5.92 -fold in response to to $100 \mu \mathrm{M}$ of $\mathrm{Mj}+100 \mu \mathrm{M} \mathrm{Cr}$. This result is in agreement with previous studies that showed vincristine and vinblastine were accumulated significantly in plants with PRX1, DAT, and STR overexpression, indicating that $P R X 1, D A T$, and $S T R$ are actively involved in the biosynthesis of these alkaloids (Pan et al., 2016). GS expression under stress has never been investigated, but from these results, it seems to have a pattern similar to $P R X 1, D A T$, and STR. Some investigations about the effects of exogenous $\mathrm{Mj}$ on the expression of the biosynthetic genes of TIA pathway has been done and all of them have shown that $\mathrm{Mj}$ cause an up regulation of many genes like G10H, TDC, STR, $\mathrm{D} 4 \mathrm{H}$, etc in this pathway (Zhang et al., 2011). Also, many abiotic stresses (like heavy metal $\mathrm{Cr}^{+6}$ ) not only increased the TIA biosynthetic genes but also induced the genes related to biosynthesis and signaling of JA (Raina et al., 2012). From these studies, we infer that both of these two exogenous treatments, $\mathrm{Mj}$ and $\mathrm{Cr}$ are participating in signal transduction pathways that cause the accumulation of TIAs in stress conditions in $C$. roseus.

The molecular and signal transduction mechanisms involved in the plant's defense against $\mathrm{Cr}$ stress was partially known, but recent findings suggest that transcriptional regulation of TIA pathway is under a complex control containing many TFs, known as ORCAs, which are regulating the primary and secondary metabolism of $C$. roseus in response to jasmonate. The TFs directly regulate the expression of many downstream stress-related genes by making a connection with the cis-elements located in the promoter region and thus leading to abiotic stress tolerance (Trinh et al., 2014). There are many reports about the role of ORCAs against various abiotic stresses in recent researches (Singh et al., 2002). Also in $C$. roseus, the elevated expression of several genes from the biosynthetic pathway of TIAs, like As, Cpr, Str, Sgd, $T d c, D 4 h$, and Dxs, due to overexpression of ORCA3 can enhance the accumulation of TIAs. Some previous studies on DAT have shown that this gene is regulated by another TF named ORCA2 (Liu et al., 2007). 

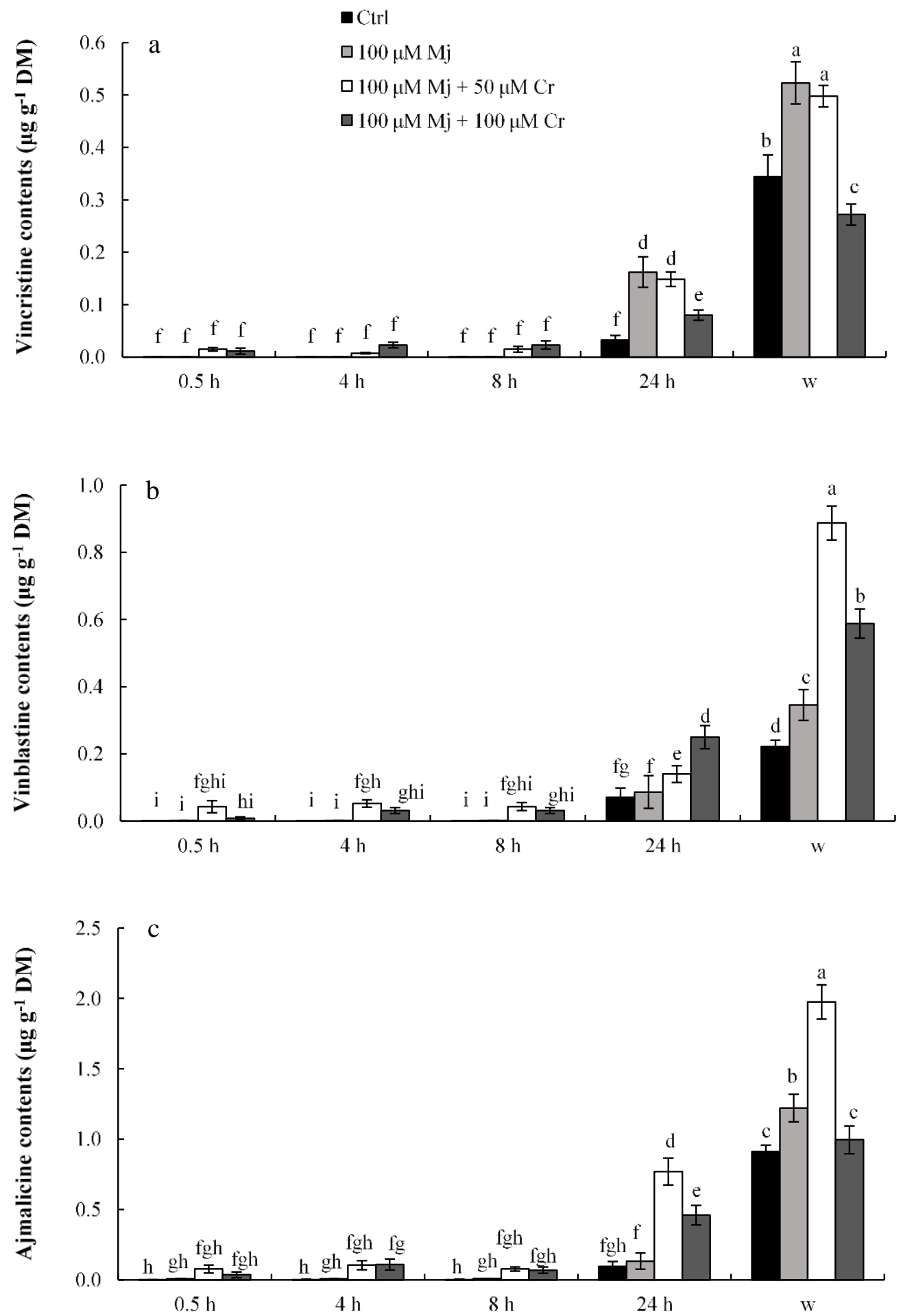

Figure 1: Effects of $\mathrm{Cr}+\mathrm{Mj}$ treatments on vincristine (a), vinblastine (b), ajmalicine (c) contents on in vitro propagated $C$. roseus shoots after $0.5,4,8,24 \mathrm{~h}$ and one week $(\mathrm{w})$ treatment. The experiments were performed in biological triplicates. Error bars indicate the standard deviations. Different letters indicate significant differences at $P<0.05$ according to Duncan test. 

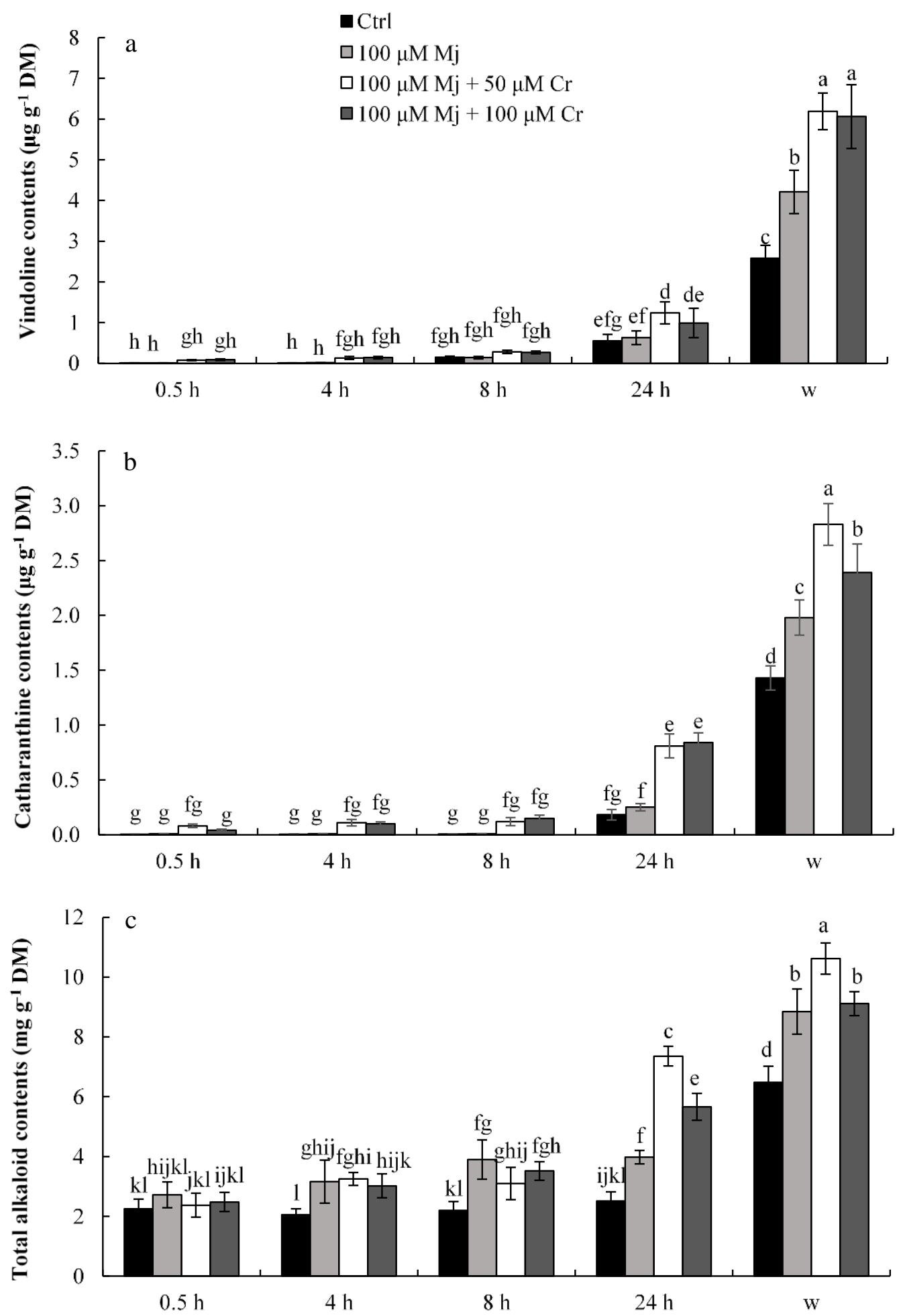

Figure 2: Effects of $\mathrm{Cr}+\mathrm{Mj}$ treatments on vindoline (a), catharanthine (b), total alkaloid (c) contents on in vitro propagated $C$. roseus shoots after $0.5,4,8,24 \mathrm{~h}$ and one week (w) treatment. The experiments were performed in biological triplicates. Error bars indicate the standard deviations. Different letters indicate significant differences at $P<0.05$ according to Duncan test. 
Internal or external signals regulate the TFs and cause controlled responses (Pan et al., 2016). Protein kinases and protein phosphatases are two main parts of signal transduction and response to stresses in plants that work through the phosphorylation and de-phosphorylation of proteins. MAPK cascade is one of these protein kinases that have several critical tasks, such as activation in defense responses to many stresses jasmonates biosynthesis, expression of jasmonate-inducible genes, responding to hormones that include ROS signaling (Dubey et al., 2010, Gao et al., 2010). In all eukaryotic cells, the activation of MAPK cascade results in the activation of TFs which convert the extracellular stimulus to intracellular responses. This cascade includes three major kinases, one of which is the MAPK that is the terminal component of this signaling cascade. MAPK3 is the most well characterized of these MAPKs. The current results showed that there was an upregulation of $O R C A 3$ and MAPK3 in response to $\mathrm{Mj}$ alone and in combination with $\mathrm{Cr}$ treatments, in consistent with Gao et al. (2010) reporting that transcription of ORCA3 and orthologs of MAPK3 in other plants were upregulated by $\mathrm{Mj}$ treatment and different stresses like high salinity, cold, heat, wounding, chitin, UV, osmotic, and oxidative stresses. The highest level of MAPK3 and ORCA3 expression was 7.67 and 5.38-fold higher than control appear $8 \mathrm{~h}$ after $100 \mu \mathrm{M}$ of $\mathrm{Mj}+50 \mu \mathrm{M}$ Cr treatment.

Based on our results, it takes a longer time to raise $S T R$, $G S, D A T$, and PRXI transcription levels compared to $M A P K 3$ and ORCA3. This is evidence of the fact that $M A P K 3$ and ORCA3 are at the beginning of the signaling pathway, activated at an early stage immediately after the induction of stress. Their expression is increased, but over time, they may influence the other defense responses and biosynthetic genes of secondary metabolites. One of the most important points that previous studies have detected about $O R C A$ and $M A P K$ is that these genes interact with each other. They may also have reciprocal regulation roles between them which elevate the expression of the TIA pathway genes to combat abiotic stress (Pan et al.,
2016). In the current work, ORCA3 and MAPK 3 reacted positively to the signals, signifying peculiar cognition and exhibited their maximal activity. They also promoted each other in the expression of TIA pathway genes to combat $\mathrm{Mj}$ and $\mathrm{Cr}$ stress. According to recent studies, abiotic stresses, for example dehydration, cold, $\mathrm{H}_{2} \mathrm{O}_{2}$ and salicylic acid (SA), initiate the signal transduction pathway which is similar for heavy metal responsive TFs (DalCorso et al., 2008). Therefore, following these findings, the mechanism of $\mathrm{Mj}$ and $\mathrm{Cr}$ may be done through two distinct ways and cross-talk across these two separate ways or stimulation of a third way by the joint attendance of $\mathrm{Mj}$ and $\mathrm{Cr}$." This could explain the increasable effect perceived for the accumulation of vinblastine and vincristine.

\subsection{Lipid peroxidation}

$\mathrm{Cr}$ as a toxic heavy metal has several effects and mechanisms to induce ROS. This is the initiation of oxidative stress, because these free radicals might mutilate the membrane architecture, cause oxidative damage, and motivate lipid peroxidation as reported in other higher plants. Here, the results (Figure 4a) suggest that combined treatment elevated the amount of lipid peroxidation after $4 \mathrm{~h}$ and one week but more precisely, $100 \mu \mathrm{M} \mathrm{Mj}+100 \mu \mathrm{M} \mathrm{Cr}$ causes significant increase in all time courses, indicates that extensive oxidative damages could have occurred to the cells under $\mathrm{Cr}$ stress especially in its higher concentrations. It was showed that $\mathrm{Cr}$, like other metals recently studied such as aluminum, lead, and arsenic, has promoted production of ROS leading to a rise in lipid peroxidation and have similar toxic effects (Sharmin et al., 2012). Also, Kupper et al. (2009) demonstrated that Mj has a strong potential to stimulate ROS production and oxidative stress with the strongest response at $100 \mathrm{mM}$ according to Kumari et al. (2015). In proceed to the previous studies, application of joint treatment in our work increased ROS production, mutilate the membrane architecture, create an oxidative damage and motivate lipid peroxidation. 

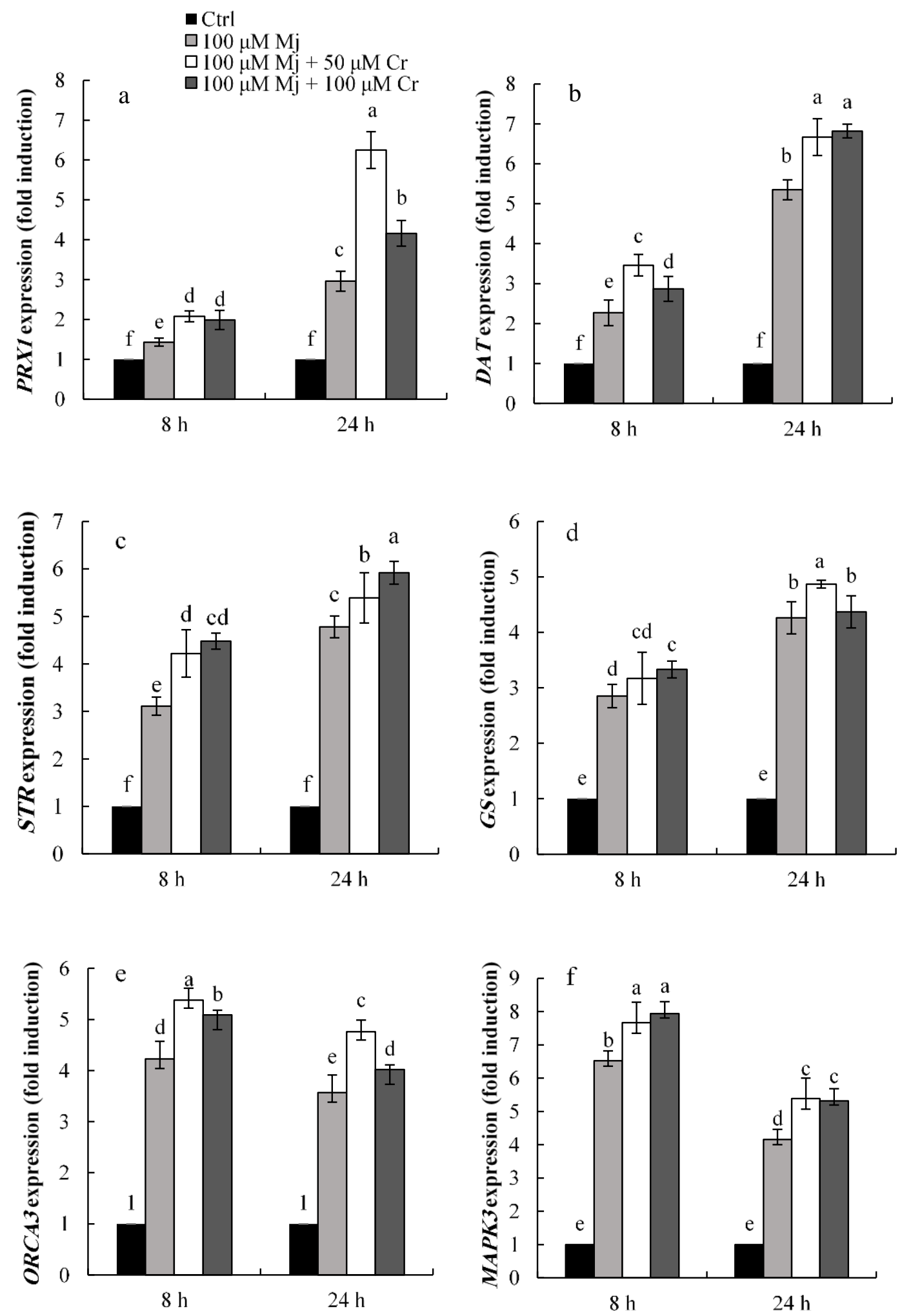

Figure 3: Effects of $\mathrm{Cr}+\mathrm{Mj}$ treatments on expression patterns of PRXI (a), DAT (b), STR (c), GS (d), ORCA3 (e), $M A P K 3$ (f) for $8 \mathrm{~h}$ and $24 \mathrm{~h}$. The experiments were performed in biological triplicates. Error bars indicate the standard deviations. Different letters indicate significant differences at $P<0.05$ according to Duncan test. 


\subsection{Phenol, flavonoid and carotenoid contents}

In addition to producing alkaloids as nonenzymatic antioxidants, carotenoids and phenolic compounds may also play a role during stress by preserving unstable macromolecules and inducing stability against metals. After $0.5 \mathrm{~h}$ treatment, there wasn't any significant difference in phenol and flavonoid contents compared to control but slowly over time, variations happened and
$\mathrm{Mj}$ alone and combined with two concentration of $\mathrm{Cr}$ caused significant increases in total phenol and flavonoid contents after $8,24 \mathrm{~h}$ and one week. The highest contents of total phenol and flavonoid (1.310 and $1.042 \mathrm{mg} \mathrm{g}^{-1} \mathrm{FM}$, respectively) were observed in the $100 \mu \mathrm{M} \mathrm{Mj}+100 \mu \mathrm{M} \mathrm{Cr}$ treatments after one week (Figures $4 \mathrm{~b}$ and $4 \mathrm{c}$ ).
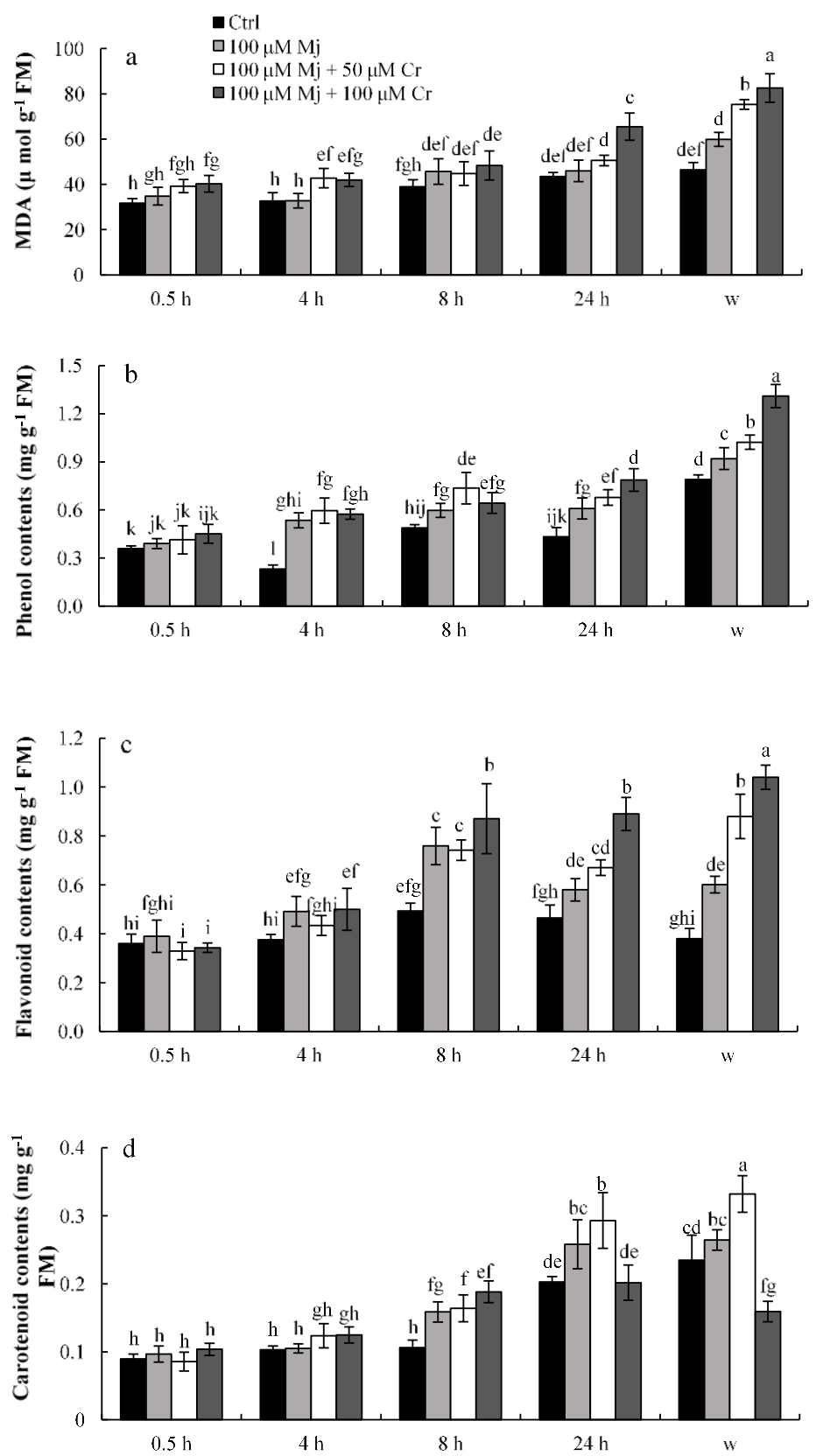

Figure 4: Effects of $\mathrm{Cr}+\mathrm{Mj}$ treatments on MDA (a) total phenol (b), flavonoid (c), carotenoid (d) contents on in vitro propagated $C$. roseus shoots after $0.5,4,8,24 \mathrm{~h}$ and one week (w) treatment. The experiments were performed in biological triplicates. Error bars indicate the standard deviations. Different letters indicate significant differences at $P<0.05$ according to Duncan test. 
This increase offered elevated defense system because the hydroxyl and carboxyl groups of these metabolites have the ability to attach metal ions like $\mathrm{Cr}$, chelate them, and thereby prevent Fenton's reaction, which is the main origin of ROS production. Flavonoids also regulate the polar transportation of auxin which controls the stomatal opening and manages the allocation of resources to help the plant overcome weak growth conditions under stress (Singh et al., 2016). The increase in total phenol and flavonoid contents in a separately heavy metal and $\mathrm{Mj}$ stress was proved in previous studies like Emamverdian et al. (2015) reviewed heavy metal effects on plants, and also the study of Ozturket al. (2015) worked on effects of preharvest $\mathrm{Mj}$ and reported matching results. İncreased contents of total phenolic and flavonoid compounds in the current work are in consonance with those studies, it also proves that the simultaneous effect of these two treatments has strengthened this antioxidant property.

C. roseus showed increased carotenoid contents after $8 \mathrm{~h}$ as a defense strategy when encountering metal stress, because these pigments protect the chlorophyll pigments and avoid the excited singlet oxygen biosynthesis. Furthermore, they suppress the photodynamic reactions and replace peroxidation. Meanwhile, it should be noted that $100 \mu \mathrm{M} \mathrm{Cr}$ significantly decreased the carotenoid contents after one week which may be again due to gradual degredation of the plant. The highest content was $0.33 \mathrm{mg} \mathrm{g}^{-1} \mathrm{FM}$ and observed in the $100 \mu \mathrm{M} \mathrm{Mj}+50 \mu \mathrm{M} \mathrm{Cr}$ treatments after one week (Figure 4d).

\subsection{Enzymatic analysis}

Plants possess another kind of defense known as enzymatic antioxidants (SOD, CAT, and POD) that act as the scavengers of free radicals. Antioxidative enzymes may behave variably in response to oxidative stresses. Antioxidative enzymes work in a contributive or synergistic manner to safeguard against oxidative stress. The current results showed after $0.5 \mathrm{~h}, \mathrm{Mj}$ combined with $50 \mu \mathrm{M} \mathrm{Cr}$ increased CAT and combined with $100 \mu \mathrm{M} \mathrm{Cr}$ increased SOD activity. Combined treatment also increased POD activities after 4, 8 and $24 \mathrm{~h}$. After one week, all treatments increased POD activity but for the two enzymes CAT and SOD, this happened only at the treatments of $\mathrm{Mj}$ alone and combined with $50 \mu \mathrm{M} \mathrm{Cr}$ and a decline at $100 \mu \mathrm{M}$ compared to $50 \mu \mathrm{M} \mathrm{Cr}$ (Figure $5 \mathrm{a}, 5 \mathrm{~b}$ and $5 \mathrm{c}$ ) was observed. This decrease may be attributed to the high affinity of $\mathrm{Cr}$ ions to thiol compounds that interrupts protein synthesis and enzyme activity (Mourato et al., 2012). As can be seen in some conditions, lower concentrations of a metal may cause an increase in enzyme activities, but using higher concentrations breaks the defense system and decreases the activities. The activation of an enzyme itself or the upregulation of its gene expression may be reasons for the increase in amounts of an enzyme. Furthermore, metals can change enzyme structures, and therefore the enzymes activities are decreased. On the other hand, it was found that $\mathrm{Mj}$ $(50$ and $100 \mu \mathrm{M})$ elevated production of numerous antioxidative enzymes and their storage (Giri \& Zaheer, 2016) so it can alleviate the oxidation by improving the ROS scavenging system stress (Jung, 2004, Aftab et al., 2011). Therefore, it is inferred that combined use of $\mathrm{Mj}$ $+\mathrm{Cr}$ induces a stronger activation of enzyme activities and these defense responses could act separately or be joined into one strategy to reduce membrane destruction and elevate cell growth or preserve cell maintenance in response to stress.

Our findings demonstrated that after $0.5 \mathrm{~h}$, combined treatments increased the protein contents. After 4,8 and $24 \mathrm{~h}$, there wasn't any significant difference but after one week only $\mathrm{Mj}$ alone significantly increased it and a significantly decrease in protein contents occurred by $100 \mu \mathrm{M} \mathrm{Cr}$ compared to other treatment groups (Figure $5 d)$. The protein rising in early hours is probably due to the plant's rapid response for launching defensive responses under stress conditions. The elevation by jasmonates may be because of induction of gene expression leading to biosynthesis of many proteins maybe proteins related to defense mechanisms, in agreement with Poonam et al. (2013) reported the accumulation of proteins induced by $\mathrm{Mj}$ in Cajanus cajan (L.) Millsp., but $\mathrm{Cr}$ induced decrease after one week might be a consequence of the elevation of catabolic enzymes like proteases, which were stimulated under $\mathrm{Cr}$ stress. Another reason is the protein denaturation and oxidation as a consequence of changes in thiol groups of proteins, which leads to increases in the production of carbonyl groups and in the rate of proteolysis that similar to our results was reported by Mourato et al. (2012).

The present study is a small-scale assay aimed at revealing the signal transduction mechanism of $C$. roseus and treatment with $\mathrm{Cr}$ and $\mathrm{Mj}$ to provide a way to produce significant values of these anticancer metabolites, the only precursors of anticancer drugs. Based on the findings, it is suggested that $\mathrm{Mj}$ responsive MAPK3 and ORCA3 are important components of the signal transduction pathway. However, full recognition of the regulatory mechanisms of this biosynthetic pathway requires further studies in this regard. 

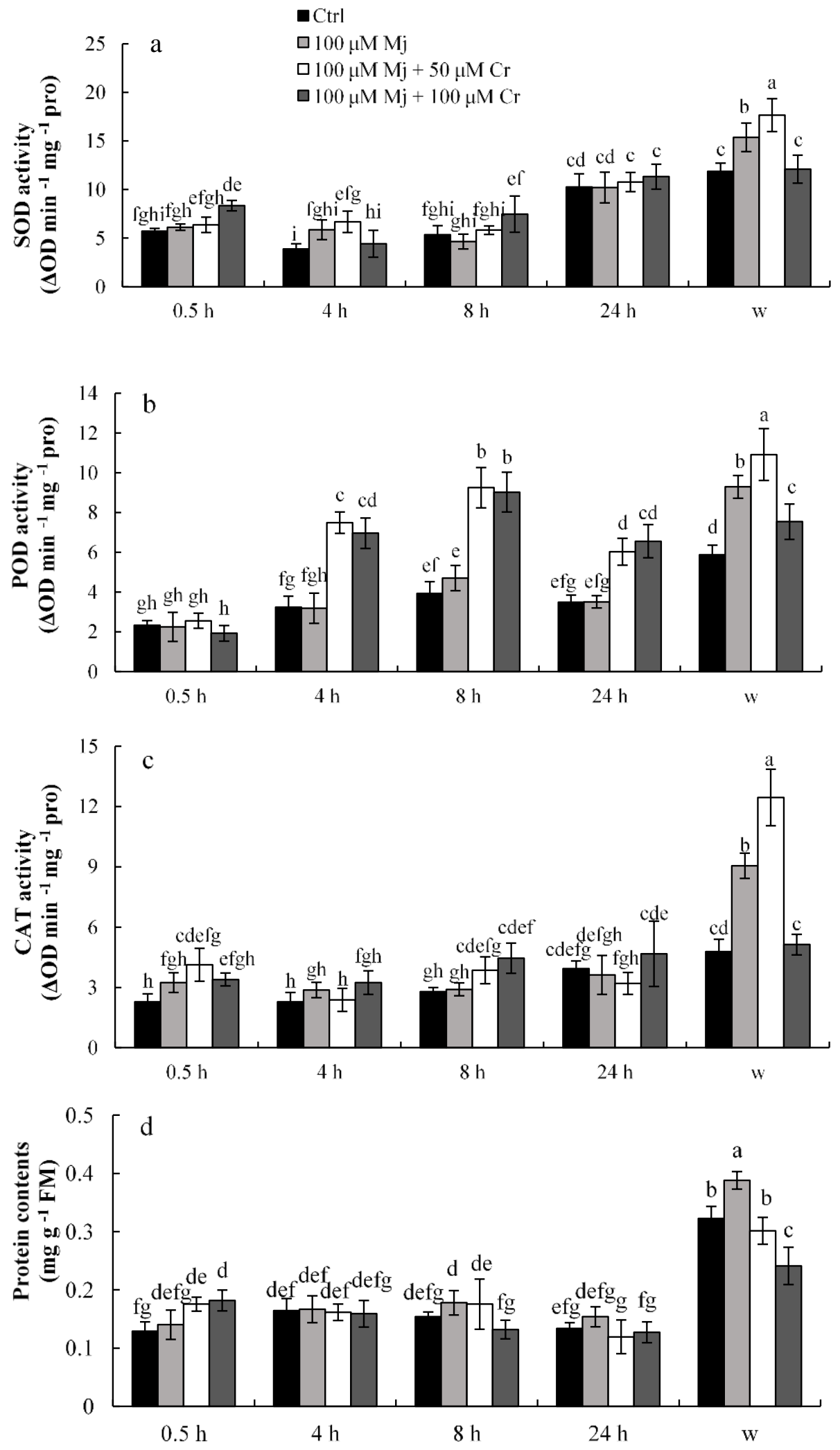

Figure 5: Effects of $\mathrm{Cr}+\mathrm{Mj}$ treatments on activities of SOD (a), POD (b), CAT(c) and protein contents (d) on in vitro propagated $C$. roseus shoots after $0.5,4,8,24 \mathrm{~h}$ and one week (w) treatment. The experiments were performed in biological triplicates. Error bars indicate the standard deviations. Different letters indicate significant differences at $P<0.05$ according to Duncan test. 


\section{CONCLUSIONS}

The results of the current study have demonstrated that combined abiotic treatments such as $\mathrm{Mj}+\mathrm{Cr}$ can influence the production of secondary metabolites and can be a commercial way to enhance the potential to overproduce medicinal valuable chemicals (here, alkaloids like vindoline, catharanthine, vincristine, vinblastine, and ajmalicine) with high pharmaceutical values. Both $\mathrm{Mj}$ and $\mathrm{Cr}$ are oxidizing agents and induce the formation of free radicals and hyperactivates the antioxidant defense system, like phenolics, flavonoids, carotenoids, and enzymes, as a part of the general stress response. However, $100 \mu \mathrm{M} \mathrm{Mj}+100 \mu \mathrm{M} \mathrm{Cr}$ showed a toxic effect on samples and reduced the alkaloids. The results of the current study agreed with a recent model named "elicitor-based signaling model" for appended stimulation of gene expression in this plant, which explained the connection of elicitor to receptor turns on the signal transduction pathway of the MAPK cascade, leading to endogenous JA biosynthesis. Increase in endogenous in addition to exogenous JA as a signal messenger activates the synthesis of nuclear proteins ORCA3. These proteins cooperate with the promoter of the biosynthetic genes and motivate the biosynthesis of TIA alkaloids.

\section{ACKNOWLEDGEMENT}

The authors would like to express thanks to Shahed University of Tehran for providing the facilities necessary to carry out the work. This research is financed in part by a grant from Medicinal Plant Research Centre of Shahed University, Tehran, Iran.

\section{REFERENCES}

Aftab, T., Khan, M. M. A., Idrees, M., Naeem, M., \& Hashmi, N. (2011). Methyl jasmonate counteracts boron toxicity by preventing oxidative stress and regulating antioxidant enzyme activities and artemisinin biosynthesis in Artemisia annua L. Protoplasma, 248(3), 601-612. https://doi.org/10.1007/s00709-010-0218-5

DalCorso, G., Farinati, S., Maistri, S., \& Furini, A. (2008). How plants cope with cadmium: staking all on metabolism and gene expression. Journal of integrative plant biology,50(10), 1268-1280. https://doi.org/10.1111/j.1744-7909.2008.00737.x

Dewanto, V., Wu, X., Adom, K. K., \& Liu, R. H. (2002). Thermal processing enhances the nutritional value of tomatoes by increasing total antioxidant activity. Journal of agricultural and food chemistry, 50(10), 3010-3014. https://doi.org/10.1021/jf0115589

Dubey, S., Misra, P., Dwivedi, S., Chatterjee, S., Bag, S. K., Mantri, S. \& Tripathi, P. (2010). Transcriptomic and metabolomic shifts in rice roots in response to $\mathrm{Cr}$ (VI) stress. BMC genomics, 11(1), 648. https://doi.org/10.1186/1471-2164-11-648

Eleftheriou, E. P., Adamakis, I. D. S., Panteris, E., \& Fatsiou, M. (2015). Chromium-induced ultrastructural changes and oxidative stress in roots of Arabidopsis thaliana. International journal of molecular sciences, 16(7), 15852-15871. https://doi.org/10.3390/ijms160715852
Emamverdian, A., Ding, Y., Mokhberdoran, F., \& Xie, Y. (2015). Heavy metal stress and some mechanisms of plant defense response. The Scientific World Journal, 2015. http://dx.doi.org/10.1155/2015/756120

Gao, F., Su, Q., Fan, Y., \& Wang, L. (2010). Expression pattern and core region analysis of AtMPK3 promoter in response to environmental stresses. Science China Life Sciences, 53(11), 1315-1321. https://doi.org/10.1007/s11427-010-4079-0

Giri, C. C., \& Zaheer, M. (2016). Chemical elicitors versus secondary metabolite production in vitro using plant cell, tissue and organ cultures: recent trends and a sky eye view appraisal. Plant Cell, Tissue and Organ Culture (PCTOC), 126(1), 1-18. https://doi.org/10.1007/s11240-016-0985-6

Heath, R. L., \& Packer, L. (1968). Photoperoxidation in isolated chloroplasts: I. Kinetics and stoichiometry of fatty acid peroxidation. Archives of biochemistry and biophysics, 125(1), 189-198. https://doi.org/10.1016/0003-9861(68)90654-1

Jung, S. (2004). Effect of chlorophyll reduction in Arabidopsis thaliana by methyl jasmonate or norflurazon on antioxidant systems. Plant Physiology and Biochemistry, 42(3), 225-231. https://doi.org/10.1016/j.plaphy.2004.01.001

Kumari, P., Reddy, C. R. K., \& Jha, B. (2015). Methyl jasmonate-induced lipidomic and biochemical 
alterations in the intertidal macroalga Gracilaria dura (Gracilariaceae, Rhodophyta). Plant and Cell Physiology, 56(10), 1877-1889. https://doi.org/10.1093/pcp/pcv115

Kupper, F. C., Gaquerel, E., Cosse, A., Adas, F., Peters, A. F., Müller, D. G. \& Potin, P. (2009). Free fatty acids and methyl jasmonate trigger defense reactions in Laminaria digitata. Plant and Cell Physiology, 50(4),

789-800. https://doi.org/10.1093/pcp/pcp023

Liu, D. H., Jin, H. B., Chen, Y. H., Cui, L. J., Ren, W. W., Gong, Y. F., \& Tang, K. X. (2007). Terpenoid indole alkaloids biosynthesis and metabolic engineering in Catharanthus roseus. Journal of integrative plant biology, 49(7), 961-974. https://doi.org/10.1111/j.1672-9072.2007.00457.x

Livak, K. J., \& Schmittgen, T. D. (2001). Analysis of relative gene expression data using real-time quantitative PCR and the $2^{-\Delta \Delta \mathrm{CT}}$ method. Methods, 25(4), 402-408. https://doi.org/10.1006/meth.2001.1262

Miranda-Ham, L., \& Islas-Flores, I. (2007). Accumulation of monoterpenoid indole alkaloids in periwinkle seedlings (Catharanthus roseus) as a model for the study of plant-environment interactions. Biochemistry and Molecular Biology Education, 35(3), 206-210. https://doi.org/10.1002/bmb.60

Mourato, M., Reis, R., \& Martins, L. L. (2012). Characterization of plant antioxidative system in response to abiotic stresses: a focus on heavy metal toxicity. In Advances in selected plant physiology aspects. InTech. https://doi.org/10.5772/34557

Ncube, B., \& Van Staden, J. (2015). Tilting plant metabolism for improved metabolite biosynthesis and enhanced human benefit. Molecules, 20(7), 12698-12731. https://doi.org/10.5772/34557

Ozturk, B., Yıldız, K., \& Ozkan, Y. (2015). Effects of pre-harvest methyl jasmonate treatments on bioactive compounds and peel color development of 'Fuji' apples. International journal of food properties, 18(5), https://doi.org/10.1080/10942912.2014.911312

Pan, Y. J., Liu, J., Guo, X. R., Zu, Y. G., \& Tang, Z. H. (2015). Gene transcript profiles of the TIA biosynthetic pathway in response to ethylene and copper reveal their interactive role in modulating TIA biosynthesis in Catharanthus roseus. Protoplasma, 252(3), 813-824. https://doi.org/10.1007/s00709-014-0718-9

Pan, Q., Mustafa, N. R., Tang, K., Choi, Y. H., \& Verpoorte, R. (2016). Monoterpenoid indole alkaloids biosynthesis and its regulation in
Catharanthus roseus: a literature review from genes to metabolites. Phytochemistry reviews, 15(2), 221-250. https://doi.org/10.1007/s11101015-9406-4

Peebles, C. A., Hughes, E. H., Shanks, J. V., \& San, K. Y. (2009). Transcriptional response of the terpenoid indole alkaloid pathway to the overexpression of ORCA3 along with jasmonic acid elicitation of Catharanthus roseus hairy roots over time. Metabolic engineering, 11(2), 76-86. https://doi.org/10.1016/j.ymben.2008.09.002

Poonam, S., Kaur, H., \& Geetika, S. (2013). Effect of jasmonic acid on photosynthetic pigments and stress markers in Cajanus cajan (L.) Millsp. Seedlings under copper stress. American Journal of Plant Sciences, 4(04), 817. https://doi.org/10.4236/ajps.2013.44100

Qu, Y., Easson, M. E., Simionescu, R., Hajicek, J., Thamm, A. M., Salim, V., \& De Luca, V. (2018). Solution of the multistep pathway for assembly of corynanthean, strychnos, iboga, and aspidosperma monoterpenoid indole alkaloids from 19Egeissoschizine. Proceedings of the National Academy of Sciences, 115(12), 3180-3185. https://doi.org/10.1073/pnas.1719979115

Raina, S. K., Wankhede, D. P., Jaggi, M., Singh, P., Jalmi, S. K., Raghuram, B. \& Sinha, A. K. (2012). CrMPK3, a mitogen activated protein kinase from Catharanthus roseus and its possible role in stress induced biosynthesis of monoterpenoid indole alkaloids. BMC plant biology, 12(1), 134. https://doi.org/10.1186/1471-2229-12-134

Sanchez-Rojo, S., Cerda-García-Rojas, C. M., EsparzaGarcía, F., Plasencia, J., Poggi-Varaldo, H. M., Ponce-Noyola, T., \& Ramos-Valdivia, A. C. (2015). Long-term response on growth, antioxidant enzymes, and secondary metabolites in salicylic acid pre-treated Uncaria tomentosa microplants. Biotechnology letters, 37(12), 2489-2496. https://doi.org/10.1007/s10529-015-1931-0

Sharmin, S. A., Alam, I., Kim, K. H., Kim, Y. G., Kim, P. J., Bahk, J. D., \& Lee, B. H. (2012). Chromiuminduced physiological and proteomic alterations in roots of Miscanthus sinensis. Plant science, 187, 113-126. https://doi.org/10.1016/j.plantsci.2012.02.002

Singh, K. B., Foley, R. C., \& Oñate-Sánchez, L. (2002). Transcription factors in plant defense and stress responses. Current opinion in plant biology, 5(5), 430-436. $\quad$ https://doi.org/10.1016/S13695266(02)00289-3

Singh, S., Parihar, P., Singh, R., Singh, V. P., \& Prasad, S. M. (2016). Heavy metal tolerance in plants: role 
of transcriptomics, proteomics, metabolomics, and ionomics. Frontiers in plant science, 6, 1143. https://doi.org/10.3389/fpls.2015.01143

Trinh, N. N., Huang, T. L., Chi, W. C., Fu, S. F., Chen, C. C., \& Huang, H. J. (2014). Chromium stress response effect on signal transduction and expression of signaling genes in rice. Physiologia plantarum, 150(2),

https://doi.org/10.1111/ppl.12088

Van der Fits, L., \& Memelink, J. (2000). ORCA3, a jasmonate-responsive transcriptional regulator of plant primary and secondary metabolism. Science, 289(5477), 295-297. https://doi.org/10.1126/science.289.5477.295

Van Moerkercke, A., Steensma, P., Schweizer, F., Pollier, J., Gariboldi, I., Payne, R. \& Kellner, F. (2015). The bHLH transcription factor BIS1 controls the iridoid branch of the monoterpenoid indole alkaloid pathway in Catharanthus roseus. Proceedings of the National Academy of Sciences, 201504951.

https://doi.org/10.1073/pnas.1504951112

Wójciak-Kosior, M., Sowa, I., Blicharski, T., Strzemski, M., Dresler, S., Szymczak, G. \& Świeboda, R. (2016). The stimulatory effect of strontium ions on phytoestrogens content in Glycine max (L.) Merr. Molecules, 21(1)

90. https://doi.org/10.3390/molecules21010090

Zhang, H., Hedhili, S., Montiel, G., Zhang, Y., Chatel, G., Pré, M. \& Memelink, J. (2011). The basic helixloop-helix transcription factor CrMYC2 controls the jasmonate-responsive expression of the ORCA genes that regulate alkaloid biosynthesis in Catharanthus roseus. The Plant Journal, 67(1), 6171. https://doi.org/10.1111/j.1365- 